\title{
Synergy between farmers' knowledge of soil quality change and scientifically measured soil quality indicators in Wanka watershed, northwestern highlands of Ethiopia
}

\author{
Wondosen Abera, Mohammed Assen \& Poshendra Satyal
}

\begin{abstract}
This study was aimed at assessing farmers' perception and knowledge of soil quality (SQ) change, in light of scientifically measured SQ indicators in the Wanka watershed, northwestern highlands of Ethiopia. Household survey, participatory SQ status assessment, key informant interview and laboratory analysis of selected SQ indicators were used as data collection tools. Independent samples $t$ test (two-tailed) was used to compare the mean difference of SQ indicators between perceived good and poor SQ status. Farmers recognized that there has been SQ decline in their farm lands over the years. Based on perceived SQ status, farmers categorized their farm plots into good, average and poor classes locally called wofram meret, boda and sis/chincha meret, respectively. The identified principal SQ status indicators used by farmers were yield, plow depth, appearance of undesired weedy plant species, fertilizer requirement of soil, topsoil color and soil workability. These farmers' assessment of SQ has well-coincided with major scientific quantitative indicators. Accordingly, plots identified by farmers as good SQ status exhibited better soil nutrients than the perceived poor SQ. Available phosphorus $(p<0.01)$ and exchangeable potassium $\left(\mathrm{K}^{+}\right)(p<0.01)$ were significantly higher in the reported good SQ plots. Conversely, sand content $(p<0.01)$ and bulk density $(p<0.05)$ were significantly high in poor SQ category. The synergy between perceived SQ status and scientifically measured SQ indicators signifies the relevance of farmers' soil knowledge in characterizing SQ status of farm plots and manage them accordingly. Thus, strategies that incorporate farmers' soil knowledge in land evaluation and sustainable land management practices should be developed and promoted.
\end{abstract}

\section{Introduction}

Soil quality (SQ) is the capacity of soil to function in response to land management and stress made by natural and human-induced factors, and can be evaluated using SQ indicators that can be assessed by qualitative or quantitative approaches (Tesfahunegn 2013; Schjønning et al. 2004). In the African context, it has been reported that SQ has been declining in smallholder farm plots, thereby leading to a reduction in crop productivity (Woniala and Nyombi 2014; Erkossa et al. 2004). Soil nutrient outflows far exceed inflows in most farming systems of sub-Saharan Africa region (Odendo et al. 2010). In many developing countries, soil nutrient mining accelerated by frequent cultivation of land is one of the main causes of SQ deterioration (Arshad and Martin 2002). In Ethiopia, agriculture shares $43 \%$ of the GDP, $85 \%$ of the employment and $70 \%$ of the country's export values (UNDP 2013), and this sector entirely depends on soil resource and its quality. However, sustainable use of soil is adversely affected by several factors, such as continuous cropping without nutrient replacement, overgrazing and human-induced land use/cover changes (Hussein et al. 2015; Teshome et al. 2014; Wassie and Shiferaw 2011). Consequently, SQ decline has resulted in poor income to farmers, low export earnings and general fall in GDP share of agriculture sector, resulting from reduced crop yield and net production (Chilot 2007).

Soil quality improvement intervention in small holder farmers is critical to feed increasing human population sufficiently. This can be realized by SQ assessment in the context of each area and extrapolate to similar area (Tesfahunegn et al. 2011). Local soil knowledge is essential as it reflects long-term understanding of farmers. Subsistence farmers in tropical region are considered to have a deep insight of their soil resource that eventually determine their management decisions (Dawoe et 
al. 2012; Amsalu and Graaff 2006). As experimenters, they are found to have acquired knowledge from generations of experience which is essential in SQ evaluation and management (Nawe and Hambati 2013; Buthelezi et al. 2010; Mairura et al. 2007; Mowo et al. 2006; Cools et al. 2003). These farmers often express SQ qualitatively in terms of observable and measurable indicators. For instance, some of the most common local SQ indicators that smallholder farmers used are an existence or growing of native floras, better crop performance (yield) and soil characteristics (e.g., workability and depth) (Barrios et al. 2006). In Ghana, top soil color, water retention capacity, stoniness and workability of soil, yield, presence of fresh worm casts and weeds are used as local SQ indicators (Dawoe et al. 2012). Similarly, crop yield, useful plant species appeared on the farm land, soil color and texture are often used to estimate SQ in KwaZulu-Natal region of South Africa (Buthelezi et al. 2010).

Generally, SQ indicators used by farmers can be grouped into soil characteristics (color, stoniness, hardness to plow, response to manure and water holding capacity), crop performance (yield, crop germination, growth rate and size) and agricultural management indicators (water availability, quantity of inorganic fertilizer required, number of crops planted or rotations (Desbiez et al. 2004). In the case of Ethiopia, farmers often describe amount of soil nutrient, bulk density, clay and soil organic matter contents in terms of yield/crop performance, existence of hard pan/compaction and soil color variation, respectively. In addition, they relate water logging for conditions related to porosity, soil looseness for soil aggregate status, and low soil water holding for sandy dominated soils (Tesfahunegn et al. 2011).

There are limited studies on farmers' perception and knowledge of SQ change of their plots over time in relation to scientifically measured SQ indicators in Ethiopia, particularly in the northwestern highlands of the country. Some empirical studies have been undertaken on farmers' local soil knowledge (Guteta and Abegaz 2016; Amsalu and Graaff 2006; Erkossa et al. 2004; Corbeels et al. 2000); however, they have been largely focused on farmers' perception of soil fertility change and adoption of land management technologies. These studies give little or no attention for analyzing the relevance of farmers' soil knowledge vis-a-vis scientific approach, and synergy between perceived and measured SQ status of farm plots. Although farmers' context-specific soil knowledge has high local relevance to understand tropical soil characteristics and management requirements; its significance needs to be verified in light of scientific approach (Odendo et al. 2010; Mairura et al. 2007; Barrios and Trejo 2003).

Understanding farmers' perception and knowledge of SQ status is critical to enhance communication and collaboration between the local farmers and scientific community, which in turn can help make effective land management interventions (Maro et al. 2013; Dawoe et al. 2012; Odendo et al. 2010; Desbiez et al. 2004; Corbeels et al. 2000). This is due to the fact that farmers' land management practice is a function of their perceived SQ status (Duruiheoma et al. 2015), and their perception also influences whether or not they will adopt soil improvement measures (Demden et al. 2005). Assessing farmers' context-specific knowledge can also facilitate its integration with scientific knowledge. This can help to develop a simple, cost-effective and less time-consuming SQ assessment methodology as well as management approaches that are required for enhancing sustainable agricultural productivity (Tesfahunegn 2013; Gruver and Weil 2007; Gray and Moran 2003). Hence, this study was aimed to examine synergy between farmers' knowledge of SQ change and scientifically measured SQ indicators in the study area.

\section{Materials and methods}

\section{The study site}


Wanka watershed is located at $11^{\circ} 29^{\prime} 24^{\prime \prime}$ and $11^{\circ} 42^{\prime} 36^{\prime \prime}$ north latitude, and at $37^{\circ} 58^{\prime} 12^{\prime \prime}$ and $38^{\circ}$ $14^{\prime} 24^{\prime \prime}$ east longitude (Fig. 1). It is one of the head streams of the Blue Nile (locally known as Abay) basin and covers a total area of $252 \mathrm{~km} 2$.

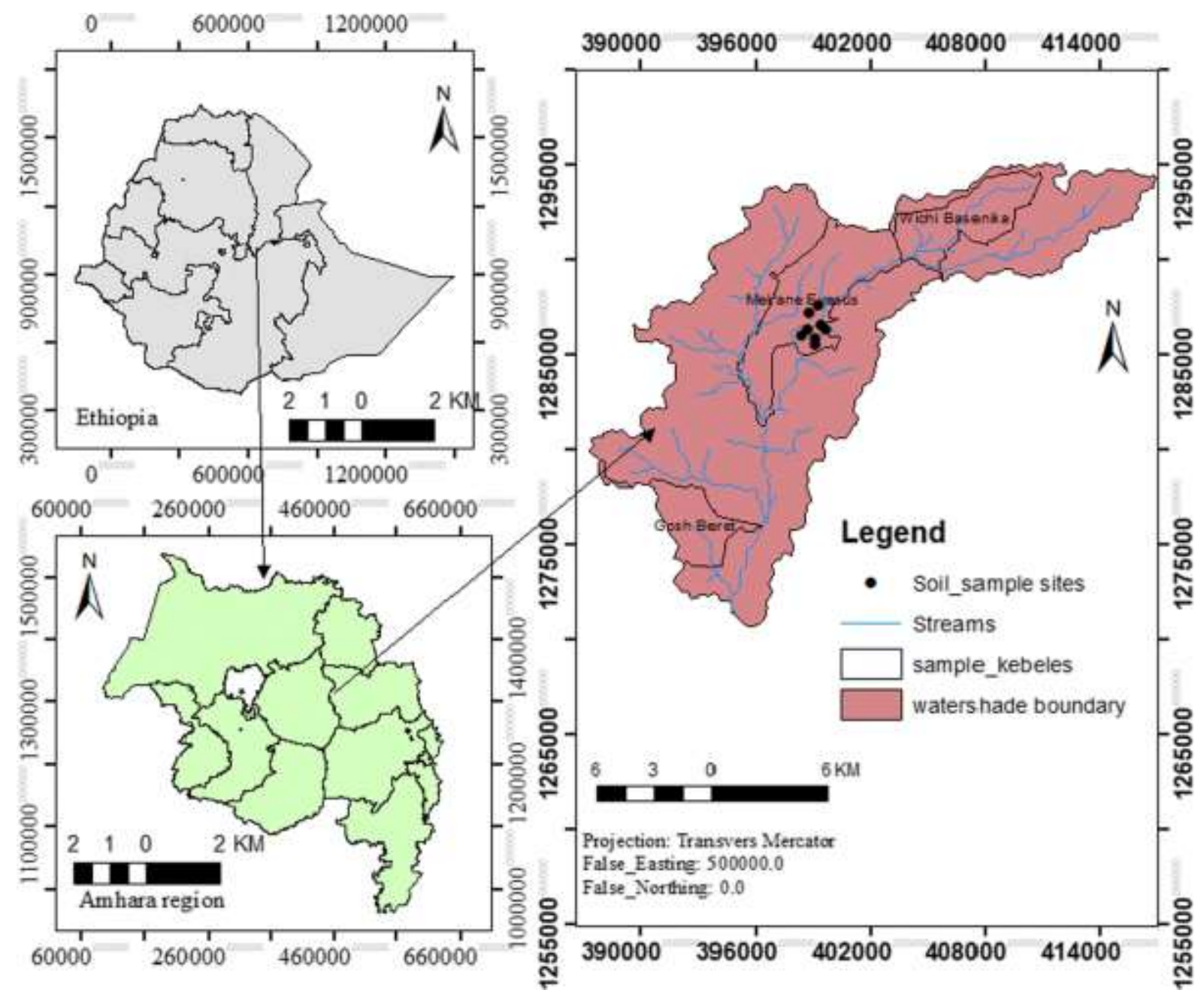

Figure 1. Location map of sample sites in Wanka watershed, northwestern highlands of Ethiopia

The watershed is a part of the extensive Afro-Arabian plateau which is characterized by uplifting of landmasses and out pouring of lava (Mohr 1971). Like that of the other headstreams of Blue Nile (Abay) basin, Wanka watershed is characterized by diverse topographic conditions. The elevation ranges from an altitude of 2238-4086 $\mathrm{m}$ above sea level (m.a.s.l.); hence, it experiences subtropical to alpine climatic conditions. Based on Ethiopian agro-ecological zonation system (Hurni 1998), Wanka watershed encompasses weyna dega (mid altitude, 1500-2300 m.a.s.l), dega (high altitude, 2300-3200 m.a.s.l), wurch (Alpine 3200-3700 m a.s.l.) and high wurch (Afro-alpine $>3700$ m.a.s.l). These agro-climatic zones account $0.5 \%, 88.8 \%, 8 \%$ and $2.7 \%$ of the studied watershed area, respectively.

The dominant soil units of the watershed are Chromic Luvisols (41.1\%), Eutric Leptosols (34.12\%) and Haplic Luvisols (24.84\%) (FAO 1990). The natural vegetation of the watershed includes grass, bushes, natural as well as plantation trees (Eucalyptus globulus and Cupressus lusitanica). The main indigenous natural tree species are weyra (Olea africana) and yabesha girar (Acacia abyssinica) in lower elevation (2238-2400 m.a.s.l), yabesha tid (Juniperus procera) in the middle elevation (24012700 m.a.s.l) and koso (Hagenia abyssinica) in upper elevation (> 2700 m.a.s.l). 
The mean annual temperature of the study area is $17.3^{\circ} \mathrm{C}$ with minimum and maximum monthly temperatures of $8.4^{\circ} \mathrm{C}$ and $26^{\circ} \mathrm{C}$, respectively. The annual rainfall recorded for the years 1994-2015 revealed that mean annual rainfall of the watershed is $1320.0 \mathrm{~mm}$. The rainfall pattern is unimodal with one major (summer) rainy season which extends from June to August, and sometimes extends up to the middle of September. About $80 \%$ of the total annual rain falls from June to September with peaking in July (369.4 mm) (NMSAE 2015).

The livelihood of the population mainly depends on a rain-fed subsistence mixed-farming system. Teff (Eragrostis abyssinica), barley (Hordeum vulgare), wheat (Tiriticum vulgare), bean (Phaseolus vulgaris), peas (Pisum sativum), chickpeas (Cicer arietinum), potato (Solanum tuberosum) and some oil seed crops are dominant crops grown in the watershed. The dominant livestock types include cattle, sheep, goats, donkey, horse, mule and poultry.

\section{Data collection}

Data for the study were acquired using structured and semi-structured survey questionnaires, participatory field survey, key informant interviews and laboratory analyses of soil samples. Key informant interview is an effective method to gain local information about soils and their management (Barrios and Trejo 2003). Major themes of the questionnaires were farmers' socioeconomic and demographic characteristics, and perception and knowledge of SQ change. Five-point Likert rating scale questionnaires that ranged from strongly agree to strongly disagree with weight of 5-1, respectively, were developed based on Desbiez et al. (2004) approach which classified SQ indicators into soil characteristic, crop performance and biological indicators (plants other than crops). Questionnaires were pretested with ten randomly selected household heads, and Cronbach's alpha $(\alpha)$ value was calculated to check the internal consistency of Likert scale perception questions, and it was found to be 0.80 . Livestock number owned by sample household was converted in Tropical Livestock unit (TLU) using conversion factors (Storck et al. 1991). Farmers were asked to list all livestock types they owned in survey questionnaire and then converted to TLU.

Multistage sampling technique was employed to select sample household heads. First, the watershed was stratified into three relative elevation classes: lower (2238-2400 m), middle (2401$2700 \mathrm{~m}$ ) and upper (2701-2828 $\mathrm{m}$ ) as there are differences in SQ and in turn indicators used by farmers across elevation variation. Then, three rural kebeles (the lowest administrative unit in Ethiopia), namely Wuchbasenqua, Mekaneyesus and Goshberet, which were fully enclosed and have upper, middle and lower altitude positions in the study watershed, were selected purposely (Fig. 1). Assuming that there is generally a homogeneity of socioeconomic condition of subsistence farmers, one village or sub-kebele (locally named as got) was randomly chosen from each sampled kebele. Thus, Washamariam, Gudiba and Goshberet were selected, respectively.

Finally, 146 household heads ( $20 \%$ of total households/HH of sampled villages) were taken randomly and proportionally for personal interview (Table 1). Household heads were a unit of analysis as they are main actors in farming activities and hence have a better understanding of soil characteristics of their farm plots. Additionally, six community elders (50-71 years old) who were engaged in farming practices for a long time (more than 30 years) and believed to have sufficient knowledge about soil quality change were selected for key informant interviews. Farmers with long farming experience have better understanding of the characteristics of their plots (Buthelezi et al. 2010). In addition, ten farmers who had better understanding of farm plots $S Q$ and were able to participate actively in the field survey were selected purposively (by consulting extension agents) for participatory field survey. Both the interviewees and participatory discussants in the field survey were male as they are the 
ones mainly engaged in plowing and have close contact with their plots, enabling them to have better understanding about the nature of their plots.

Table 1 Characteristics of sampled villages in the Wanka watershed.

\begin{tabular}{lllll}
\hline Villages & $\begin{array}{l}\text { Relative position in } \\
\text { the Watershed }\end{array}$ & Elevation (meter) & Total HH size & Sample size \\
\hline Washamariam & Upper & $2,701-2,828$ & 287 & 58 \\
Gudiba & Middle & $2,401-2,700$ & 180 & 37 \\
Goshberet & Lower & $2,238-2,400$ & 250 & 51 \\
Total & & & 717 & 146 \\
\hline
\end{tabular}

$\mathrm{HH}=$ households

Source: field survey

\section{Soil sampling}

Out of the three selected sample kebeles for household survey interview, one kebele (Mekaneyesus) was randomly selected for soil sampling. Then, as stated above, ten farmers were selected purposively from those who were selected for survey questionnaires interview to classify and describe plots based on their SQ status during soil sampling. Only ten farmers were selected as it was assumed that this number was manageable. The number of participants needs to be manageable in order to facilitate the discussion and arrive at consensus easily (Tesfahunegn 2013). Farmers were asked to identify and describe plots that they perceive to have contrasting SQ (poor and best) through transect walk (Dawoe et al. 2012; Gruver and Weil 2007; Desbiez et al. 2004). While farmers classified plots into poor and best SQ status, they were asked to describe local biological SQ indicators (prevalent plant species other than crops), crop performance and soil characteristics indicators used by them to characterize plots (Barrios et al. 2006; Desbiez et al. 2004). Finally, synergy between perceived and scientifically measured SQ status was evaluated (Fig. 2).

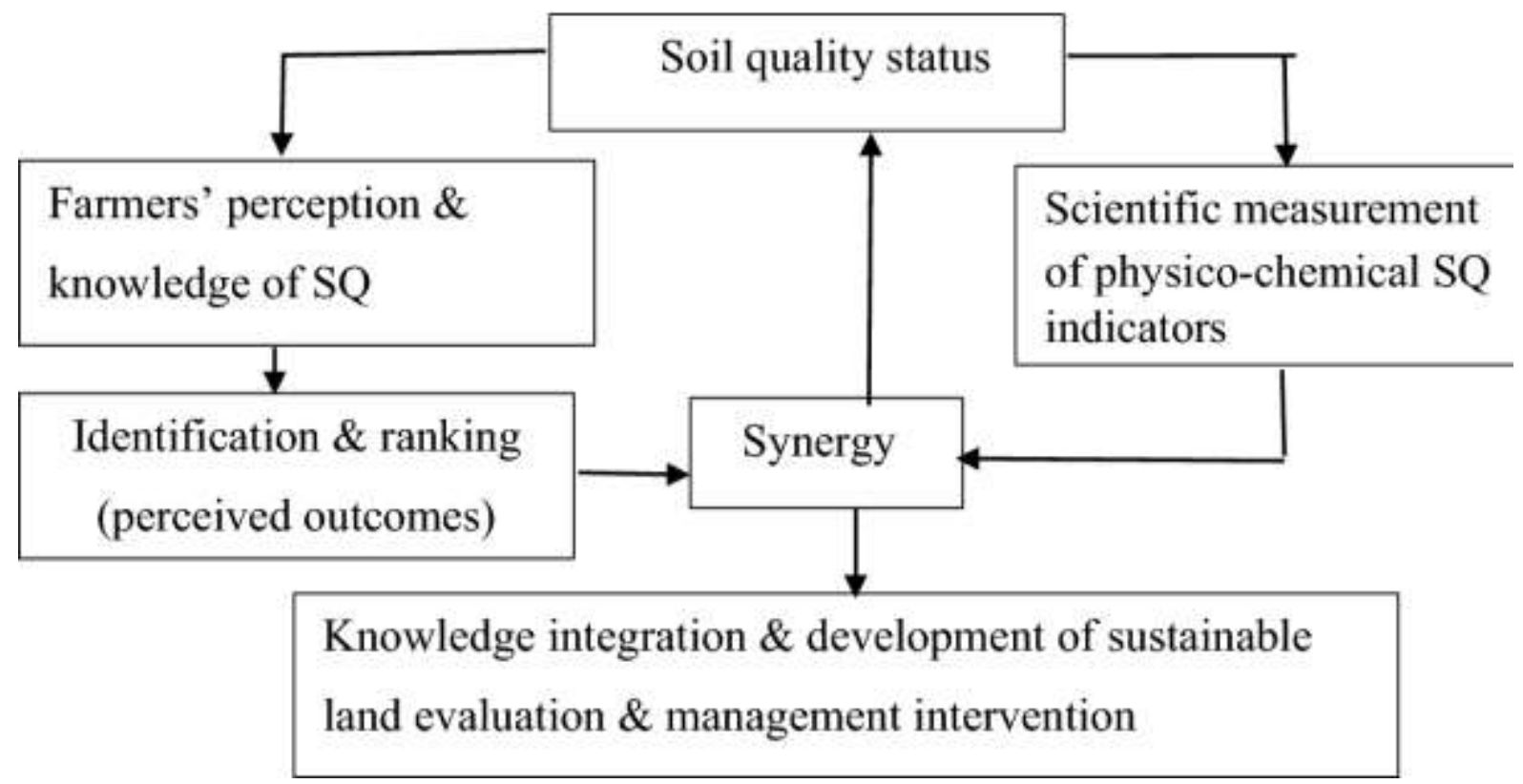

Figure 2. Flow graph of synergy between perceived and measured SQ status analyses 
Eight plots $(20 \mathrm{~m} \times 20 \mathrm{~m})$, having similar slope position and which were under Teff (Eragrostis abyssinica) (predominant crop in the area) for the previous cropping season, were identified by farmers. Eight disturbed composite soil samples (four for perceived best and four for poor SQ) each having five subsamples (composite) were taken using auger following $\mathrm{X}$-shaped sampling patterns at the depth of $0-20 \mathrm{~cm}$. Topsoil was used as it contains significant proportion of soil nutrients (Abegaz et al. 2016; Arshad and Martin 2002), and farmers have main concern with topsoil as it is relevant for agricultural production (Buthelezi et al. 2010). Subsamples were mixed, and approximately 0.5-1 $\mathrm{kg}$ of composite sample from each sample plot was prepared, put in plastic bag, labeled and carried to the laboratory for analysis. In addition, undisturbed soil samples from each sampled plot were taken from the center of each plot using a core sampler for analysis of bulk density and moisture contents. Soil sampling was conducted after harvesting period (January), and prior to collecting the soil samples from cultivated lands, permission was obtained from the landowners.

Soil samples analysis was carried out following standard scientific analytical methods and procedures at Adet Agricultural Research Center's soil laboratory in Ethiopia. Prior to the analysis, samples were air-dried at room temperature and grounded to pass through 2-mm sieve. The standard methods were adopted to examine 19 SQ indicators. Bouycous hydrometric and core sampler methods were, respectively, used to determine soil particle size distribution and bulk density (BD) analysis (Estefan et al. 2013). Total porosity was calculated by assuming a particle density of $2.65 \mathrm{~g} \mathrm{~cm}-3$, that is, $\mathrm{P}=(1-\mathrm{BD} / \mathrm{PD}) * 100$, where $\mathrm{P}=$ total porosity $(\%), \mathrm{BD}=$ the bulk density $(\mathrm{g} \mathrm{cm}-3)$ and $\mathrm{PD}=$ assumed particle density $(\mathrm{g} \mathrm{cm}-3)$ (Landon 1991). Soil water content at field capacity (FC) and permanent wilting point (PWP) was determined at $1 / 3$ and 15 bars, respectively, by pressure membrane suction method, and available water content (AWC) was determined by calculating their differences (Estefan et al. 2013).

Soil pH was measured in 1:2.5 soil-water ratio suspension (Van-Reeuwijk 2002). As suggested by Carter and Gregorich (2006) Kjeldahl, Olsen and Walkley-Black oxidation methods were, respectively, used to determine total nitrogen (TN) available phosphorus (Av. Ph) and soil organic carbon (SOC). Soil organic matter (SOM) was determined by multiplying (SOC\%) by a constant factor of 1.724 (Carter and Gregorich 2006). Cation exchange capacity (CEC) and exchangeable bases (K+, $\mathrm{Mg} 2+, \mathrm{Ca} 2+$ and $\mathrm{Na}+$ ) were extracted by ammonium acetate extraction method (at pH 7) as described by Estefan et al. (2013). Exchangeable potassium $(\mathrm{K}+)$ and sodium $(\mathrm{Na}+)$ were measured by flame photometer, whereas exchangeable calcium $(\mathrm{Ca} 2+)$ and magnesium $(\mathrm{Mg} 2+)$ were read using atomic absorption spectrometer (AAS). Then, percent base saturation (PBS) was calculated by dividing the sum of exchangeable cations to CEC and multiplying by 100 (Estefan et al. 2013).

\section{Statistical analysis}

Descriptive statistics and independent samples t test were employed to analyze household survey and soil data, respectively. Independent samples t test (two-tailed) is used to compare the mean difference of SQ indicators between perceived best and poor SQ status (Muzangwa et al. 2017; Salehi and Maleki 2012). SPSS_IBM version 23 was used to analyze quantitative data.

\section{Results and discussion}

Households' socio-economic and demographic characteristics

As shown in Table 2, significant proportions (94.5\%) of the sampled households were male headed, and only $5.5 \%$ were female headed. Most male-headed respondents $(93 \%)$ were married, whereas female-headed households (7\%) were either divorced or widowed. The minimum and maximum ages of the respondents were, respectively, 24 and 80 years with average and modal ages of 52 and 45 years, respectively. The family size of the households was within the range of 1-10 with the 
average of 6 . Like the other parts of rural Ethiopia, substantial proportions of the respondents $(62.3 \%)$ were illiterate and only $37.7 \%$ were literate.

Table 2 Socio-economic and demographic characteristics of farmer households $(n=146)$ in the Wanka watershed.

\begin{tabular}{|c|c|c|c|c|}
\hline \multirow[b]{2}{*}{ Characteristics } & \multicolumn{2}{|c|}{ Sample villages } & \multirow[b]{2}{*}{$\begin{array}{l}\text { Goshberet } \\
(n=51)\end{array}$} & \multirow{2}{*}{$\begin{array}{l}\text { Total } \\
\text { (146) }\end{array}$} \\
\hline & $\begin{array}{l}\text { Washamariam } \\
(\mathrm{n}=58)\end{array}$ & $\begin{array}{l}\text { Gudiba } \\
(n=37)\end{array}$ & & \\
\hline \multicolumn{5}{|l|}{ Sex (\%) } \\
\hline Male & 96.6 & 92 & 94 & 94.5 \\
\hline Female & 3.4 & 8 & 6 & 5.5 \\
\hline \multicolumn{5}{|l|}{ HH age(years) } \\
\hline Mean & 53 & 51 & 51 & 52 \\
\hline SD & 8.7 & 8.9 & 10.5 & 9.57 \\
\hline \multicolumn{5}{|c|}{ Marital status (\%) } \\
\hline Single & 10.3 & 2.7 & 6 & 7 \\
\hline Married & 89.7 & 97.3 & 94 & 93 \\
\hline \multicolumn{5}{|c|}{ Educational status (\%) } \\
\hline Illiterate & 59.6 & 61 & 64 & 62.3 \\
\hline Literate & 40.4 & 39 & 36 & 37.7 \\
\hline \multicolumn{5}{|l|}{ Family size } \\
\hline Mean & 6.2 & 6.1 & 6.2 & 6.2 \\
\hline SD & 1.3 & 1.9 & 1.8 & 1.66 \\
\hline \multicolumn{5}{|c|}{ Landholding size (ha) } \\
\hline Mean & 1.08 & 1.08 & 1.21 & 1.12 \\
\hline SD & 0.33 & 0.35 & 0.30 & 0.33 \\
\hline \multicolumn{5}{|c|}{ Livestock number (TLU) } \\
\hline Mean & 5.3 & 5.1 & 5.03 & 5.14 \\
\hline SD & 1.6 & 1.4 & 1.1 & 1.4 \\
\hline
\end{tabular}

Source: field survey

$\mathrm{HH}=$ household head, ha=hectare, $\mathrm{TLU}=$ tropical livestock unit, SD=standard deviation

The land hold size of respondent households ranged between 0.25 ha (hectare) and 2 ha with average size of $1.12 \mathrm{ha}$, which is slightly greater than the national average of 0.90 ha and lower than the regional average of 1.15 ha (CSA 2007). However, over half of the households (55\%) owned $0.25-1$ ha. This has an implication as low per capita landholding size can create pressure on sustainable utilization of land resource. As stated by key informant interviewees, available landholding size of the $\mathrm{HH}$ is not sufficient enough to support their family size. This has aggravated overuse of available land resource, leading to deterioration of $\mathrm{SQ}$, and thereof reduction in land productivity. The mean livestock holding was found to be 5.14 in TLU. There was, however, a difference in land and livestock holding size between different altitudinal positions. The average landholding size of farmers in the sampled upper altitude village was found relatively lower than in the lower and middle altitude villages.

\section{Farmers' perception of SQ change}

Farmers possess knowledge of soil characteristics of their farm plots that often remains unknown to the scientific community (Buthelezi et al. 2010). In the Wanka watershed, farmers generally perceive that SQ status has deteriorated over time in their plots. In our household survey, most of the respondents (83.6\%) reported a decline of SQ in their plots, while a few $(16.4 \%)$ suggested that SQ 
has not declined (Table 3). As to the trend, about 79.5\% of farmers reported that SQ decline has been increasing over time. Conversely, $11.6 \%$ stated that there was no trend of SQ decline, whereas 8.9\% of farmers reported that there was an improvement in SQ status as compared to the previous years. On the other hand, more than half of the respondents $(57.5 \%)$ explained the severity of the problem (Table 3). An interviewee (69 years old) in Washamariam kebele stated the problem of SQ decline in his locality as follows:

Soil quality of farm lands has declined over time as farm lands are tired/exhausted. This is caused by repeated cultivation without fallowing (locally called Asha or Tigat), as the land shortage has been increasing over the years. Previously (three/four decades ago), it was possible to get much yield from a small plot for home consumption as well as for the market with minimum effort (land was soft, very fertile and did not require intensive management) and without any fertilizer application. But, nowadays, we are even struggling to fulfill home consumption sufficiently, as the productivity of plots has been reduced year after year. Some plots have reached at the point that we are not able to produce much even with application of fertilizer.

Table 3 Farmers' perception of SQ change and its trend (\%) in the Wanka watershed

\begin{tabular}{clcll}
\hline Responses (\%) & \multicolumn{3}{c}{ Sample villages } & Total \\
\cline { 2 - 3 } & $\begin{array}{l}\text { Washamariam } \\
(\mathrm{n}=58)\end{array}$ & $\begin{array}{l}\text { Gudiba } \\
(\mathrm{n}=37)\end{array}$ & $\begin{array}{l}\text { Goshberet } \\
(\mathrm{n}=51)\end{array}$ & $\begin{array}{l}\text { (146) } \\
\text { Existence of SQ decline }\end{array}$ \\
yes & 89.7 & 78.4 & 80.4 & 16.4 \\
no & 10.3 & 21.6 & 19.6 & 79.5 \\
$\begin{array}{c}\text { Trend of SQ decline } \\
\text { increasing }\end{array}$ & 77.6 & 89.2 & 78.4 & 11.6 \\
no change & 13.8 & 5.4 & 13.7 & 8.9 \\
decreasing & 8.6 & 5.4 & 7.9 & 4.1 \\
Severity of SQ decline & & & 2 & 38.4 \\
light & 5 & 5.4 & 35.3 & 57.5 \\
moderate & 26 & 62.2 & 62.7 & \\
severe & 69 & 32.4 & & \\
\hline
\end{tabular}

In the study area, a decline of SQ was related to abandoning of fallowing practice, repeated cultivation, absence of or little fertilizer application (as indicator of soil nutrient decline), and consequently a low yield and/or instability or decline of yield and soil compaction. This implies that land management practices in the study area have been practiced poorly, mainly perhaps due to land fragmentation resulting from population pressure, and high cost of inorganic fertilizer. Unaffordable cost of fertilizer, farm land shortage and disintegration hinder farmers to practice land management effectively (Corbeels et al. 2000).

\section{Famers' rating of soil quality change indicators}

Farmers recognized a decline of major SQ indicators in their plot, for which they used various indicators to differentiate $S Q$ status of the plots. The principal indicators identified by farmers in the case study included: increasing fertilizer requirement of soil $(M=4.15, S D=0.77)>$ decreasing depth of plow/hoe layer $(M=4.14, S D=0.85)>$ yield reduction $(M=4.12, S D=1.071)>$ soil erosion incidence $(M=4.10, S D=0.891)>$ increasing weed infestation $(M=3.93, S D=1.072)>$ increasing soil compaction ( $M=3.67, S D=1.161)(F i g .3)$. These indicators are mainly associated with soil physical 
(e.g., soil compaction, stoniness) and biological characteristics (e.g., weed infestation), and agricultural productivity (yield). They are interrelated, easily observable and identifiable by farmers through their long-time farming experience and context-specific knowledge (Buthelezi et al. 2010; Dawoe et al. 2012; Desbiez et al. 2004). Increasing fertilizer requirement of soil is a reflection of soil nutrients losses, which results in yield reduction. Thus, farmers' rating of high fertilizer requirement of plots as top SQ decline indicators in Wanka watershed implies deterioration of soil nutrients perhaps due to continuous cultivation without proper soil fertility management. Crop yield decline is mainly attributed to continuous and repeated cultivation of land without any soil quality enhancement methods (Mairura et al. 2007). Moreover, farmers' rating of SQ decline indicators suggests the prevalence of land degradation in the area, as decreasing depth of plow layer and soil compaction are indicators of land degradation.

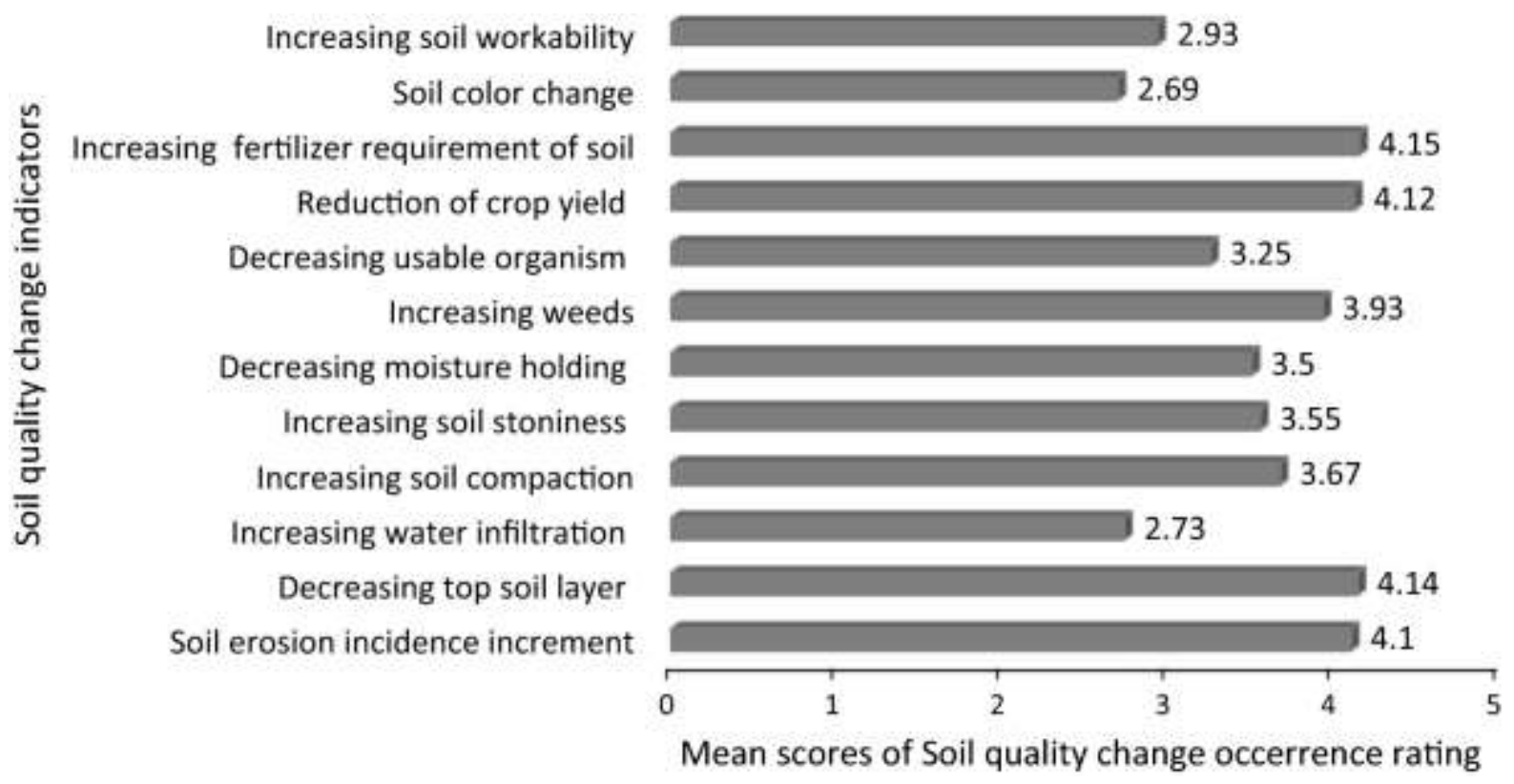

Figure 3. Farmers' rating of SQ change indicators in their plots

\section{Participatory SQ assessment and terminologies used by farmers}

It is difficult to measure SQ directly, rather it is inferred from farmers' visual assessment and use of local indicators (Mairura et al. 2007). Hence, identifying farmers' indicators of SQ is invaluable in SQ assessment process. Smallholder farmers in the Wanka watershed categorized their farm plots into good, average and poor SQ classes. In common parlance locally, these correspond to wofram meret (plot having thick top soil layer, good fertility and productivity), boda (plot with average top soil layer, fertility and productivity) and chincha/sis meret (plot with thin and compact top soil layer and poor productivity), respectively. Local farmers consider a multiple of criteria such as soil physical properties, crop performance and yield, topographic and management factors in evaluating their plots' SQ status (Table 4). Similarly, these indicators have been used by farmers in central and northern highlands Ethiopia, and western Kenya (Tesfahunegn et al. 2011; Odendo et al. 2010; Erkossa et al. 2004). 
Table 4 Farmers' indicators of soil quality in Wanka watershed, northwestern Ethiopia

\begin{tabular}{lll}
\hline Major SQ indicators & \multicolumn{1}{c}{ Description } & Poor SQ/chincha meret \\
\cline { 2 - 3 } Plough thickness and stoniness & Best SQ/Wofram meret & $\begin{array}{l}\text { Has shallow layer in most cases with stoniness and some part } \\
\text { rock outcrop. Thus, it is difficult to plough (not easily penetrated } \\
\text { with plough). }\end{array}$ \\
Moisture content & Has thick plough layer which is easy to plough. & $\begin{array}{l}\text { Has low moisture holding capacity; growing crops susceptible to } \\
\text { susceptible to dry spell }\end{array}$
\end{tabular}

\section{Topsoil color}

Types of crop grown

Seedling appearance (crop growing condition) and yield

\section{Weeds infestation}

Presence of erosion indicators

Management requirement

Topographic location

\section{In most cases, it has black top soil color}

Used for cultivation of all types of locally grown crops (Teff, barley, wheat, maize, potato, bean, peas, chickpea, lentil, oil seeds).

Good germination and growth, vigorous and healthy crops. Gives reasonably good yield for most cultivated crops. Depending on local soil productivity potential, it can give 3-6 quintals Teff per hectare

Little or no weeds infestation

little or no appearance of erosion indicators

Little or no special management requirement. Requires no/little chemical fertilizer

Mostly located in flat/gentle slope area
Has white/light color

Used for cultivating only few crops (bean, peas and Lupines lupine or 'gibto' which are useful for land improvement)

Less seeds germinate, unevenly grown, stunted growth, less vigorous and gives low crop yield (about 2-3 quintals of Teff per hectare)

High weeds infestation and predominance over crops, needs much labor for weeding

Appearance of erosion incidence indicators e.g. gullies, rock outcrop.

Requires intensive management practice. Needs more chemical fertilizer and even less responsive

Mostly located in steep slope gradients 

Farmers in the study area differentiate plots with good and poor SQ in light of soil properties parameters such as, topsoil color, plow layer (workability), stoniness and moisture holding capacity of soil, as perhaps these indicators are easily identifiable. They consider black soil (most likely pheaozems and vertisols) locally called walka as fertile and productive soils. This implies that farmers are able to identify soil having better soil nutrients and organic matter contents. In the scientific context, the black soil (locally walka) shows prevalence of well-decomposed organic matter (humus) and clayey texture. The clay fraction usually has a net negative charge that adsorbs nutrient cations $(\mathrm{Ca} 2+, \mathrm{Mg} 2+$, and $\mathrm{K}+)$ and retains them in available form for use by roots and microbes (Foth 1990). Farmers explain that walka soil is sticky in wet seasons and become clody and hard in dry seasons, hence these make plowing difficult. It is used for cultivation of primarily Teff and chickpeas. This is due to clayey texture of walka soil which increases its moisture and nutrient holding capacity.

Farmers also evaluate SQ through depth of plow layer. Wofram meret, mainly homestead plots are locally called Yemarese meret, which means well-fertilized plot with organic fertilizer that is released from home, has thick workable top soil layer and gives high yield. This is associated with the proximity of the plots to farmers' home, which enables farmers to practice organic manure management practices with minimum labor cost (application of animal manure/dung and compost). As studied elsewhere (Tesfahunegn et al. 2011), intensive plot management practices are widely practiced around homesteads plots which maximize SQ. This suggests that land or soils which are easily accessed for management can be considered as one of the factors for SQ improvement. Conversely, plots with poor SQ (locally called sis/chincha) have many stones in their surfaces and have shallow soils depth, and hence plow is not able to penetrate easily, resulting in highly degraded status of the soils. This is perhaps because of removal of arable layer due to erosion. In that sense, the use of local term chincha that means stony, difficult to plow and unproductive land rightly reflects the SQ characteristics.

In our participatory assessment, farmers considered the degree of soil management requirement as one of the criteria to evaluate SQ status of the plots. They verified that soil with poor quality would require intensive management practices such as application of fertilizer and labor for weeding (as there is often high fertilizer requirement and weed infestation). Conversely, in fertile soils (e.g., homestead plots), crop cultivation requires no/less soil management practice. This implies that farmers understand that high yield or high soil productivity is dependent on optimum soil fertility and management status.

Yield, types of grown crops and weeds in a given land or soils were also regarded as additional local indicators to evaluate SQ. Farmers considered that plots with good SQ give high yield without application of fertilizers, but in poor SQ, yield is low, and there is a wide possibility of less seeds germination, unevenly and stunted crop growth (locally called Mechachat that means poor crop growth) (Table 4). They estimated that Teff (dominantly cultivated crop in the area) yield per hectare in plots with good and poor SQ was about 3-6 quintals and 2-3 quintals, respectively. Farmers also verified that plots with best SQ grow all or most types of locally grown crops. This kind of plot is locally called yesetutin yemekebel meret, which means plots that is suitable for cultivation of any crops. Conversely, plots with poor SQ are used to cultivate only few crops like bean, peas, Lupines lupine or 'gibto' and potato. Thus, local farmers in our case study use similar indicators like the farmers in Ghana and Kenya who mainly relate SQ as a reflection of yield and crop performance (Dawoe et al. 2012; Mairura et al. 2007).

Farmers have also considered the types of weedy plant species growing in their plots as another indicator of SQ. In fact, SQ is also a reflection of prevalence of various plant species (Omari et al. 2018). If locally useful weeds or plants grow in a given area, the soils could be considered as the best SQ soil. Local plants like muja (Snowdenia polystachya), asndabo (Echinochloa pyramidalis), sama 
(Urtica simensis), yayitareg (Ipomea purpurea) and gaja sar (Andropogon gayanus) are very commonly found in plots with good SQ (Wofram meret) classes (Table 5). On the other hand, plants or weeds such as serti (Asparagus africanus) wariyat (Digitaria abyssinica) and yebeg lat (Corrigiola capensis) were found in poor SQ (sis meret) soil classes (Table 5). According to our key informant interviewees, these plants appeared in so-called tired or exhausted soil and when this happened, plots were mainly used for bean, peas and Lupines lupine or 'gibto' cultivation to improve soil quality (locally called kulessa), and sometimes rotated for grass land or fallow for certain period. This type of knowledge has allowed the local farmers to reconsider management strategies, as their lifelong farming experience has made them aware about various SQ status indicator plants. Farmers in Colombia, Hondurans and Venezuela have also used various plant species as indicator of SQ (Barrios and Trejo 2003). Studies conducted elsewhere in the world also revealed that farmers used various plant species to differentiate plots SQ status. For example, in Nepal, farmers reported that plants like A. conyzoides L., Ageratum houstonianum Mill, P. nepalense Meissn, G. parviflora Cav. are prevalent in fields with good SQ. On the other hand, plants such as Oplismenus spp., Digitaria spp., B. ramose, Imperata spp. and Echinochloa spp. mushroomed in poor SQ field (Desbiez et al. 2004). Similarly, in Ghana plants like Chromolaena odorata with large green leaves and grassy weeds are common in reported good and poor SQ plots (Dawoe et al. 2012).

Table 5 Local plants used by farmers to indicate SQ in Wanka watershed.

\begin{tabular}{|l|l|l|l|l|}
\hline Plants' local name & Scientific name & Botanical family & $\begin{array}{l}\text { SQ classes in } \\
\text { which plants } \\
\text { are prevalent }\end{array}$ & $\begin{array}{l}\text { Reported local plots } \\
\text { classes according to their } \\
\text { SQ status }\end{array}$ \\
\hline Muja & Snowdenia polystacyya & Poaceae & Best SQ & Wofram Meret \\
\hline Sama & Urtico simensis & Urticaceae & Best SQ & Wofram Meret \\
\hline Asndabo & Echinochola pyramidalis & Poaceae & Best SQ & Wofram Meret \\
\hline Yayit-hareg & Ipomea purpurea & Convolvnlacea & Best SQ & Wofram Meret \\
\hline Gaja sar & Andropogon gayanus & Poaceae & Best SQ & Wofram Meret \\
\hline Mech /Adoye & Bidens scabra & Asteracean & Poor SQ & Chicha/Dedeh Meret \\
\hline Wariyat & Digitaria abyssinica & Poaceae & Poor SQ & Chicha /Dedeh Meret \\
\hline Yebeg lat & Corrigiola capensis & Molluginaceace & Poor SQ & Chicha/Dedeh Meret \\
\hline Serti & Asparagus africanus & Asparagaceae & Poor SQ & Chicha /Dedeh Meret \\
\hline Gench & Avena abyssinica & Poaceae & Poor SQ & Chicha/Dedeh Meret \\
\hline
\end{tabular}

Source: field survey

$\mathrm{SQ}=$ soil quality

Topographic attributes or location of soils in a landscape was also one of the SQ indicators used in the Wanka watershed. Farmers identified that farm plots in steep slope area (locally called tedafat meret) are poor in its $\mathrm{SQ}$, as they are often characterized by excessive water drain to down slope and existence of erosion incidence indicators (e.g., gullies). Conversely, soil in flat area accumulates eroded materials from steep slope that improves its productivity. This implies, farmers often relate topographic characteristics and erosion incidence with soil properties and SQ.

\section{Synergy between perceived SQ status and measured SQ indicators}

As shown in Table 6, the mean value of essential soil nutrients in plots that were perceived and identified by farmers as the best SQ (locally called Wofram meret) was found higher. Available phosphorus (Av.ph) and exchangeable potassium $(K+)$ values were significantly $(p<0.01)$ higher in perceived best SQ than poor SQ (locally called sis meret) category. This implies that perceived poor SQ plots are highly degraded (low soil nutrient and organic matter contents) than perceived good SQ which corresponded to the scientific measurements (Table 6). The amounts of both Av.ph and 
exchangeable $\mathrm{K}+$ in perceived best and poor SQ were rated as high and low, respectively (Landon 1991) (Table 6). Similarly, while the amount of soil organic matter (SOM) in both perceived good and poor SQ was found low (Landon 1991), it was significantly $(p<0.05)$ higher in perceived best soil than in poor SQ class. Exchangeable K+ was found to be low in perceived poor SQ soil, which reflects the repeated plowing of the plots and occurrences of soil erosion. Continuous cultivation accentuates erosion and removal of plant nutrients available in the soil (Mengiste et al. 2015). Total porosity was also found significantly $(p<0.05)$ higher in perceived good than in poor SQ class. The observed amount of total porosity in perceived good and poor SQ was under optimum and low categories, respectively (Landon 1991). Although the amount of measured $\mathrm{pH}$ value in both perceived good and poor SQ class was found within the preferred range for most crops (5.6-6.05), it was significantly $(p<0.01)$ higher in the perceived good SQ. This implies that perceived poor SQ plots are highly degraded (low soil nutrient and organic matter contents) than perceived good SQ which corresponded to the scientific measurements (Table 6). 
Table 6. Comparison of SQ indicators in perceived good and poor SQ classes (0-20 cm depth) of the Wanka watershed

\begin{tabular}{|c|c|c|c|c|c|c|c|c|c|}
\hline \multirow{2}{*}{$\begin{array}{l}\text { Scientific SQ } \\
\text { indicators }\end{array}$} & \multicolumn{3}{|c|}{ Perceived good SQ } & \multicolumn{3}{|c|}{ Perceived poor SQ } & \multirow[b]{2}{*}{ t-values } & \multirow[b]{2}{*}{$\mathrm{df}$} & \multirow[b]{2}{*}{$P$ value } \\
\hline & $\begin{array}{l}\text { Measured } \\
\text { value }\end{array}$ & $\begin{array}{l}\text { Farmers' } \\
\text { rating }\end{array}$ & Scientific rating & $\begin{array}{l}\text { Measured } \\
\text { value }\end{array}$ & $\begin{array}{l}\text { Farmers' } \\
\text { rating }\end{array}$ & Scientific rating & & & \\
\hline Sand (\%) & 24 & \multirow{18}{*}{ 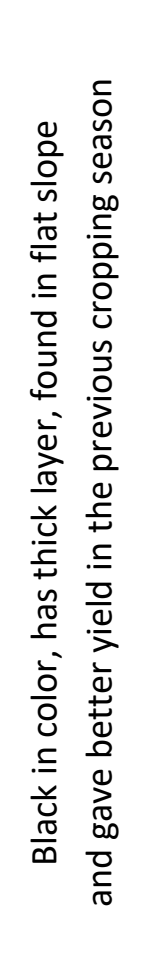 } & Clayey texture & 33 & \multirow{18}{*}{ 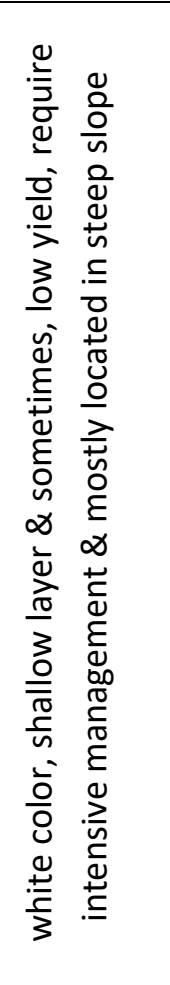 } & clay loam texture & -6.930 & 6 & $0.000 * *$ \\
\hline Silt (\%) & 33 & & & 33 & & & 0.078 & 6 & 0.941 \\
\hline Clay (\%) & 43 & & & 34 & & & 2.330 & 6 & 0.059 \\
\hline $\mathrm{BD}\left(\mathrm{g} \mathrm{cm}^{-3}\right)$ & 1.2 & & optimum & 1.4 & & optimum & -2.895 & 6 & $0.028 *$ \\
\hline Total Porosity (\%) & 54 & & optimum & 46 & & Low & 2.893 & 6 & $0.028 *$ \\
\hline FC (\%) & 46 & & & 43 & & & 1.590 & 6 & 0.163 \\
\hline PWP(\%) & 22 & & & 22 & & & 0.409 & 6 & 0.697 \\
\hline$A W C(\%)$ & 24 & & & 21 & & & 1.878 & 6 & 0.109 \\
\hline $\mathrm{pH} \mathrm{H} \mathrm{H}_{2} \mathrm{O}(1: 2.5)$ & 6.05 & & medium(optimum) & 5.6 & & medium (optimum) & 4.839 & 6 & $0.003 * *$ \\
\hline SOM (\%) & 2.4 & & Low & 1.9 & & Low & 3.554 & 6 & $0.012 *$ \\
\hline Av. Ph (ppm) & 36 & & high & 4 & & low & 6.740 & 6 & $0.001 * *$ \\
\hline TN (\%) & 0.3 & & medium & 0.2 & & Low & 1.433 & 6 & 0.202 \\
\hline CEC $\left(\mathrm{Cmolc} \mathrm{kg}^{-1}\right)$ & 27 & & high & 26 & & high & -0.148 & 6 & 0.887 \\
\hline $\mathrm{Ca}^{2+}\left(\mathrm{Cmolc} \mathrm{kg}^{-1}\right)$ & 22 & & high & 21 & & high & 0.490 & 6 & 0.642 \\
\hline $\mathrm{Mg}^{2+}\left(\mathrm{Cmolc} \mathrm{kg}^{-1}\right)$ & 3.9 & & medium & 4 & & medium & -1.193 & 6 & 0.278 \\
\hline $\mathrm{K}^{+}\left(\mathrm{Cmolc} \mathrm{kg}^{-1}\right)$ & 0.8 & & high & 0.3 & & Low & 5.201 & 6 & $0.002 * *$ \\
\hline $\mathrm{Na}^{+}\left(\mathrm{Cmolc} \mathrm{kg}^{-1}\right)$ & 0.03 & & Low & 0.04 & & Low & -0.171 & 6 & 0.870 \\
\hline BS (\%) & 104 & & high & 96 & & high & 1.812 & 6 & 0.120 \\
\hline
\end{tabular}

* significant at $p<0.05 * *$ significant at $p<0.01$

$\mathrm{SD}=$ standard deviation, $\mathrm{df}=$ degree of freedom, $\mathrm{BD}=$ bulk density, $\mathrm{Av}$.ph=available phosphorus, $\mathrm{TN}=$ total nitrogen, $\mathrm{C} / \mathrm{N}=$ carbon nitrogen ratio, $\mathrm{CEC}=$ cation exchange capacity, Ex. Ca2+=exchangeable calcium, Ex. Mg2+ = exchangeable magnesium, Ex. $\mathrm{K}+=$ exchangeable potassium, Ex. Na+ = exchangeable sodium, $\mathrm{PBS}=$ percent base saturation, $\mathrm{GSQ}=$ good soil quality, $\mathrm{PSQ}=$ poor soil quality 

The overall findings of the study show that farmers' traditional knowledge and experience of SQ characterization in Wanka watershed concur well with scientifically measured SQ indicators. This signifies that farmers in the study area have sufficient understanding of the SQ status of their plots. Farmers' differentiation of good SQ using their own indicators such as black topsoil color, thick plow layer and less management requirement (low supply of inputs) is a reflection of prevalence of soil nutrients and organic matter in this SQ class. A similar observation was made in western Kenya where a higher $\mathrm{pH}$ and exchangeable cation was reported in perceived good SQ class (Mairura et al. 2007). Conversely, sand content $(p<0.01)$ and bulk density (BD) $(p<0.05)$ were significantly higher in perceived poor SQ category in our study area (Table 6). However, BD in both perceived good and poor SQ was within the optimum range (not causing root restriction) (Landon 1991).

\section{Implication of synergy between perceived SQ status and measured SQ indicators}

Assessment of farmers' perception and local knowledge about SQ changes in light of scientifically measured SQ indicators is essential to check the relevance of their context-specific knowledge for soil and land management. This enables the scientific community to validate and incorporate farmers' local knowledge into SQ assessment and sustainable land management practices (Tesfahunegn 2013; Dawoe et al. 2012; Desbiez et al. 2004; Barrios and Trejo 2003). In the study watershed, it was found that farmers' perceived SQ status coincided with scientifically measured major SQ indicators. This could be related to the lifelong close contact of the local farmers with their plots which enabled them to develop deep understanding of soil characteristics of their plots.

Farmers reported production of relatively high yield in perceived good SQ (wofram meret), which implies, in scientific terms, a good availability of basic soil nutrients in the soil (soil organic matter, nitrogen, potassium and phosphorus) and higher cation exchange capacity (Dawoe et al. 2012; Mairura et al. 2007). On the other hand, farmers noticed thin plow layer and low yield in poor SQ (chincha/sis meret). This corresponds with scientific indicators of poor SQ, such as the prevalence of low soil organic matter and biological activity in such plots.

Our results, thus, show that in the study area, the local farmers are able to characterize their plots accurately and easily. They know the type of land use that needs to be practiced in accordance with the SQ status of the land. Besides, determining their land use type based on the SQ of plots, the local farmers also know the required management practice for the plots. For example, for the plots with poor SQ, they adopt a number of local measures to reverse its quality, including cultivation of leguminous crops, changing to grass land temporarily or keeping it fallow for some time. This type of local knowledge and experience on soil management can have indispensable contribution in evaluation and management practices of land resource. We recommend that synergies between local/traditional and scientific knowledge need to be explored and encouraged further, as the absence of effective linkage between farmers' and conventional soil knowledge is one of the major problems that has hindered agricultural development in the developing world (Getahun 2006).

\section{Conclusion}

This study demonstrates that local farmers are well-familiar with the characteristics of their plots. This enables them to have a deep understanding and knowledge in characterizing the soil quality status of their farm lands with their own indicators accurately and subsequently practice required land use systems. In Wanka watershed, the local farmers recognized a trend of decline in soil quality in their plots. The main traditional indicators used by farmers to assess soil quality were depth of plow and softness, yield, presence of weeds, and soil color. In the scientific context too, these indicators correspond well and are largely linked with fertility, soil depth, organic matter content and textural condition of the soil. Farmers considered black soil as fertile, giving high yields, which 
on scientific assessment also showed a higher content of soil organic matter. Farmers' qualitative identification of soil quality also corresponded with a number of major scientific quantitative indicators used in our assessment. Soil nutrients (available phosphorus and potassium) were found significantly higher in perceived good soil quality status than the poor one. These results thus imply that local farmers have invaluable soil knowledge and hence, policy makers and experts need to consider and give emphasis for collecting, assessing and using farmers' knowledge and experience on soil quality identification and management. Strategies that encourage active participation of farmers in land evaluation and sustainable land management practices are critical to maximize sustainable agricultural development. Finally, further studies that investigate the synergies between scientific and local indicators on soil quality such as botanical nature of plants identified by farmers as SQ indicators in relation to soil nutrients are needed.

\section{References}

Abegaz, A., Winowiecki, L. A., Vågen, T. G., Langan, S., \& Smith, J. U. (2016). Spatial and temporal dynamics of soil organic carbon in landscapes of the upper Blue Nile basin of the Ethiopian highlands. Agriculture, Ecosystems \& Environment, 218, 190-208.

Amsalu, A., \& Graaff, J. D. (2006). Farmers' views of soil erosion problems and their conservation knowl- edge at Beressa watershed, central highlands of Ethiopia. Agriculture and Human Values, 23, 99-108.

Arshad, M. A., \& Martin, S. (2002). Identifying critical limits for soil quality indicators in agroecosystems. Agriculture, Ecosystems \& Environment, 88, 153-160.

Barrios, E., Delve, R. J., Bekunda, M., Mowo, J., Agunda, J., \& Ramisch, J. (2006). Indicators of soil qual- ity: A South-South development of a methodological guide for linking local and technical knowledge. Geoderma, 135, 248-259.

Barrios, E., \& Trejo, M. T. (2003). Implications of local soil knowledge for integrated soil management in Latin America. Geoderma, 111, 217-231.

Buthelezi, N., Hughes, J., \& Albert, M. (2010). The use of scientific and indigenous knowledge in agricul- tural land evaluation and soil fertility studies of two villages in KwaZulu-Natal, South Africa. In 19th world congress of soil science, soil solutions for a changing world, August 2023.

Carter, M. R., \& Gregorich, E. G. (2006). Soil sampling and methods of analysis. Saskatoon: Canadian Society of Soil Science.

Chilot, Y. (2007). The dynamics of soil degradation and incentives for optimal management in the Central highlands of Ethiopia. PhD dissertation, University of Pretoria.

Cools, N., Pauw, E. D., \& Deckers, J. (2003). Towards an integration of conventional land evaluation meth- ods and farmers' soil suitability assessment: A case study in Northwestern Syria. Agriculture, Ecosys- tems \& Environment, 95, 327-342.

Corbeels, M., Abebe, S. \& Mitiku, H. (2000). Farmers' knowledge of soil fertility and local management strategies instrategies in Tigray, Ethiopia. Managing Africa's Soils, No. 10.

CSA (Central Statistical Agency). (2007). The federal democratic republic of Ethiopia central statistical agency, Agricultural Sample Survey, Volume IV.

Dawoe, E. K., Quashie-sam, J., Isaac, M. E., \& Oppong, S. K. (2012). Exploring farmers' local knowledge and perceptions of soil fertility and management in the Ashanti region of Ghana. Geoderma, 179-180(2012), 96-103.

Demden, F. H., Llewellyn, R. S., \& Burton, M. P. (2005). Adoption of conservation tillage in Australia crop- ping regions: An application of duration analysis. Technological Forecasting and Social Change, 73, 630-647.

Desbiez, A., Matthews, R., Tripathi, B., \& Ellis-jones, J. (2004). Perceptions and assessment of soil fertility by farmers in the Mid-Hills of Nepal. Agriculture, Ecosystems \& Environment, 103, 191-206. 
Duruiheoma, F. I., Burek, C. V., Bonwick, G., \& Alexander, R. (2015). Farmers' perception of soil: Impli- cations for soil conservation \& sustainable agriculture in the UK. Global Journal of Agricultural Research, 3(3), 11-24.

Erkossa, T., Stahr, K., \& Gaiser, T. (2004). Participatory soil quality assessment: The case of smallholder farmers in Ethiopian highlands. Australian Journal of Soil Research, 42, 793-797.

Estefan, G., Sommer, R., \& Ryan, J. (2013). Methods of soil, plant and water analysis: A manual for the West Asia \& North Africa region, 3rd edn. Beirut: International Center for Agricultural Research in theDry Areas (ICARDA).

FAO (Food \& Agricultural Organization of the United Nations). (1990). FAO/UNESCO Soil Map of the World Revised Legend, Rome.

Foth, H. D. (1990). Fundamentals of soil science (8th ed.). New York: Wiley.

Getahun, F. (2006). Farmers' indigenous knowledge the missing link in the development of Ethiopian agriculture: A case study of Dejen district, Amhara region. Social Science Research Report Series, No.34. Gray, L. C., \& Moran, P. (2003). Reconciling indigenous knowledge with scientific assessment of soil fertility changes in Southwestern Burkina Faso. Geoderma, 111, 425-437.

Gruver, J. B., \& Weil, R. R. (2007). Farmer perceptions of soil quality and their relationship to management-sensitive soil parameters. Renewable Agriculture and Food Systems, 22(4), 271-281.

Guteta, D., \& Abegaz, A. (2016). Farmers' perception of soil fertility change and their Preferences for soil fertility management techniques for different land use types in Arsamma watershed, Southwestern Ethiopian highlands. International Journal of Environmental Studies, 73(1), 108-121.

Hurni, H. (1998). Agroecologial belts of Ethiopia: Explanatory notes on three maps at a scale of 1:1,000,000. Research Report, Soil Conservaton Research Program, Addis Ababa, Ethiopia.

Hussein, H., Mohammed, A., \& Nicolau, M. D. (2015). Impact of land cover changes and topography on soil quality in the Kasso catchment, Bale mountains of southeastern Ethiopia. Singapore Journal of Tropical Geography, 36, 357-375.

Landon, J. (1991). Booker Tropical Soil Manual: A Hand Book for soil survey \& agricultural land evaluation in the tropics and subtropics. New York: Wiley.

Mairura, F., Mugendi, D., Mwanje, J., Ramisch, J., \& Mbugua, P. (2007). Assessment of farmers' perceptions of soil quality indicators within smallholder farms in the central highlands of Kenya. In A. Bationo, B. Waswa, J. Kihara, \& J. Kimetu (Eds.), Advances in integrated soil fertility management in sub-Saharan Africa: Challenges and opportunities. Dordrecht: Springer.

Maro, G. P., Mrema, J. P., Msanya, B. M., \& Teri, J. M. (2013). Farmers' perception of soil fertility problems and their attitudes towards integrated soil fertility management for Coffee in Northern Tanzania. Journal of Soil Science and Environmental Managemen, 4(5), 93-99.

Mengiste, W., Mohammed, M., \& Yitebarek, T. (2015). Evaluation of effect of land use types on selected soil physicochemical properties in Itang-Kir area of Gambella region, Ethiopia. Journal of Biology, Agriculture and Healthcare, 5, 13.

Mohr, P. J. (1971). The geology of Ethiopia. Addis Ababa: Haile-Selassie I University Press.

Mowo, J. G., Janssen, B. H., Oenema, O., German, A., Mrema, J. P., \& Shemdoe, R. S. (2006). Soil fertility evaluation and management by smallholder farmer communities in Northen Tanzania. Agriculture, Ecosystems \& Environment, 116, 47-59.

Muzangwa, L., Mnkeni, P. N. S., \& Chiduza, C. (2017). Assessment of conservation agriculture practices by smallholder farmers in the Eastern Cape province of South Africa. Agronomy, 7, 46.

Nawe, J. \& Hambati, H. (2013). Integrating traditional and modern knowledge systems in improving agricultural productivity in Upper-Kitete village, Tanzania. Presented at REPOA's 18th Annual Research Workshop held at the Kunduchi Beach Hotel, Dares Salaam, Tanzania. 
NMSAE (National Meteorological Service Agency of Ethiopia). (2015). Temperature and rain fall data of Mekaneyesus town (Addis Ababa: Unpublished Document).

Odendo, M., Obare, G., \& Salasya, B. (2010). Farmers' perceptions and knowledge of soil fertility degradation in two contrasting sites in western kenya. Land Degradation \& Development, 21, 557-564.

Omari, R. A., Dorothea, S., Kimura, B., Addo, E. S., Oikawa, Y., \& Yoshiharu, F. Y. (2018). Explor- ing farmers' indigenous knowledge of soil quality and fertility management practices in selected farming communities of the Guinea savannah agro-ecological Zone of Ghana. Sustainability, 10(4), 1034. https://doi.org/10.3390/su10041034.

Salehi, A., \& Maleki, M. (2012). Evaluation of soil physical and chemical properties in poplar plantations in North of Iran. Ecologia Balkanica, 4(2), 69-76.

Schjønning, P., Elmholt, S., \& Christensen, B. T. (2004). Managing soil quality: Challenges in modern agriculture. Foulum Tjele: Danish Institute of Agricultural Sciences Research Centre.

Storck, H., Bezabih, E., Berhanu, A., Borowiecki, A. \& Shimelis, W. (1991). Farming systems and farm management practices of smallholders in the Hararghe highlands-A baseline Survey. Farming systems and resource economics in the tropics, 11. Wissenschaftsverlag Vauk, Kiel, Germany.

Tesfahunegn, G. B. (2013). Soil quality indicators response to land use and soil management systems in Northern Ethiopia's catchment. Land Degradation and Development, 27, 438-448.

Tesfahunegn, G. B., Tamene, L., \& Vlek, P. L. G. (2011). Evaluation of soil quality identified by local farmers in Mai-Negus catchment, northern Ethiopia. Geoderma, 163, 209-218.

Teshome, A., Graaff, J. D., Ritsema, C., \& Kassie, M. (2014). Farmers' perceptions about the influence of land quality, land fragmentation and tenure systems on sustainable land management in the north western Ethiopian highlands. Land Degradation \& Development, 27, 884-898.

UNDP (United Nations Development Program in Ethiopia). (2013). Annual Report. www.et.undp.org. Accessed 23 Jan 2019.

Van-Reeuwijk, L. P. (2002). Procedures for soil analysis (6th ed.). Wageningen: International Soil Reference and Information Center.

Wassie, H., \& Shiferaw, B. (2011). On-Farm verification of lime and NPK fertilizers effects on the Tuber yield of Irish potato (Solanum tuberosum) on some acidic soils of Southern Ethiopia. Journal of the Dry Lands, 4(1), 283-288.

Woniala, J., \& Nyombi, K. (2014). Soil fertility management by smallholder farmers and the impact on soil chemical properties in Sironko district, Uganda. Research Journal of Agriculture and Forestry Sciences, 2(1), 5-10. 